ISSN 2073-4409

www.mdpi.com/journal/cells

Review

\title{
The Possible Roles of the Dentate Granule Cell's Leptin and Other Ciliary Receptors in Alzheimer's Neuropathology
}

\section{James F. Whitfield ${ }^{1, *}$, Anna Chiarini ${ }^{2}$, Ilaria Dal Prà ${ }^{2}$, Ubaldo Armato ${ }^{2}$ and Balu Chakravarthy ${ }^{1}$}

1 Human Health Therapeutics, National Research Council of Canada, Ottawa, ON K1A 0R6, Canada; E-Mail: balu.chakravarthy@nrc-cnrc.gc.ca

2 Histology \& Embryology Unit, Department of Life \& Reproduction Sciences, University of Verona Medical School, 8 Strada Le Grazie, Verona, Venetia 37134, Italy; E-Mails: anchiari@gmail.com (A.C.); ippdalpra@gmail.com (I.D.P.); uarmato@gmail.com (U.A.)

* Author to whom correspondence should be addressed; E-Mail: pthosteo@rogers.com; Tel.: +613-722-2209.

Academic Editors: Gang Dong and William Tsang

Received: 19 May 2015 / Accepted: 6 July 2015 / Published: 13 July 2015

\begin{abstract}
Dentate-gyral granule cells in the hippocampus plus dentate gyrus memory-recording/retrieving machine, unlike most other neurons in the brain, are continuously being generated in the adult brain with the important task of separating overlapping patterns of data streaming in from the outside world via the entorhinal cortex. This "adult neurogenesis" is driven by tools in the mature granule cell's cilium. Here we report our discovery of leptin's LepRb receptor in this cilium. In addition, we discuss how ciliary LepRb signaling might be involved with ciliary $\mathrm{p} 75^{\mathrm{NTR}}$ and SSTR3 receptors in adult neurogenesis and memory formation as well as attenuation of Alzheimer's neuropathology by reducing the production of its toxic amyloid- $\beta$-derived drivers.
\end{abstract}

Keywords: adult neurogenesis; Alzheimer's disease; amyloid- $\beta$; amyloid- $\beta$ oligomers; ciliary LepRb; dentate gyrus; hippocampus; hyperphosphorylated tau; leptin; memory formation; $\mathrm{p} 75^{\mathrm{NTR}}$; somatostatin receptor 


\section{Introduction}

This is a story about a set of extremely important receptor proteins found in the primary cilium protruding from each of the very special little granule cells or neurons of the dentate gyrus, which is part of the ancient hippocampal memory-recording machinery in the brain's temporal lobes [1]. We are starting to realize now that these receptors are used to build retrievable memories and with them model our outside worlds. One such receptor is LepRb, the functional full-length, signaling receptor of leptin (from the Greek leptos meaning thin), a 16-kDa cytokine adipostat, mainly from white fat adipocytes. When carried across the blood-brain-barrier into the hypothalamus, leptin restrains feeding by firing STAT3 (signal transducer and activator of transcription 3), PI3K (phosphoinositide 3-kinase)/Akt (Ak thymoma kinase)/MAPK (mitogen-activated protein kinase)-ERK (extracellular signal-regulated kinase) pathway signals from LepRb into its hypothalamic target cells [2-4].

However, we now know that leptin influences many more brain-based functions. The LepRb receptor is expressed in the amygdala, the cerebral cortex, and the hippocampal CA1 field. As comprehensively reviewed by Tezapsidis et al. [5] and more recently by Irving and Harvey [6], evidence is mounting that leptin and the cascade of signals from LepRb may arrest Alzheimer's disease (AD). Indeed convincing evidence supporting leptin-based therapy for $\mathrm{AD}$ has been summarized by Neurotez Inc. (Bridgewater, NJ, USA) [7]. However, before going further with the LepRb story, we must first understand the role of dentate gyrus and its ciliated granule cells in memory formation, the developing failure of which is the first detectable sign of on-coming AD.

\section{The Contribution of the Dentate Gyrus to Memory Formation}

During a person's daily activities, the various sensors send streams of data to the different primary sensory regions of the cerebral cortex. Most of these are not retained long enough to be projected into the reverberating core network (i.e., the medial and lateral prefrontal cortices, the posterior cingulate and retrosplenial cortices, temporal lobes, and the hippocampus and the associated dentate gyrus) for further processing into a conscious image or "neuronal video" [8]. However, some of the data is sent to the hippocampal formation via the EC (entorhinal cortex) hub where the neurons in layer II process the converging polymodal data for transmission to the memory-encoding machinery in the hippocampal CA3 field and to the dentate gyral granule cells [9-16] (Figure 1).

However, during a person's customary daily activities, there is the problem of overlapping data streaming into the hippocampus and dentate gyrus. An efficient memory-recording machine that can fulfill the basic need of a mammal to adapt to a changing environment must be able to separately record even closely similar experiences without producing synaptic palimpsests. Moreover, this machinery must later be able to retrieve these stored component patterns or individual "chunks" and reassemble them into valid though usually experientially modified memories. Therefore, there must be a device that can distinguish overlapping input patterns to enable separate memory storage and retrieval. That device is the dentate gyrus and pattern separation and memory resolution is its job $[10-13,17,18]$. In other words, the dentate gyrus prevents palimpsests. 


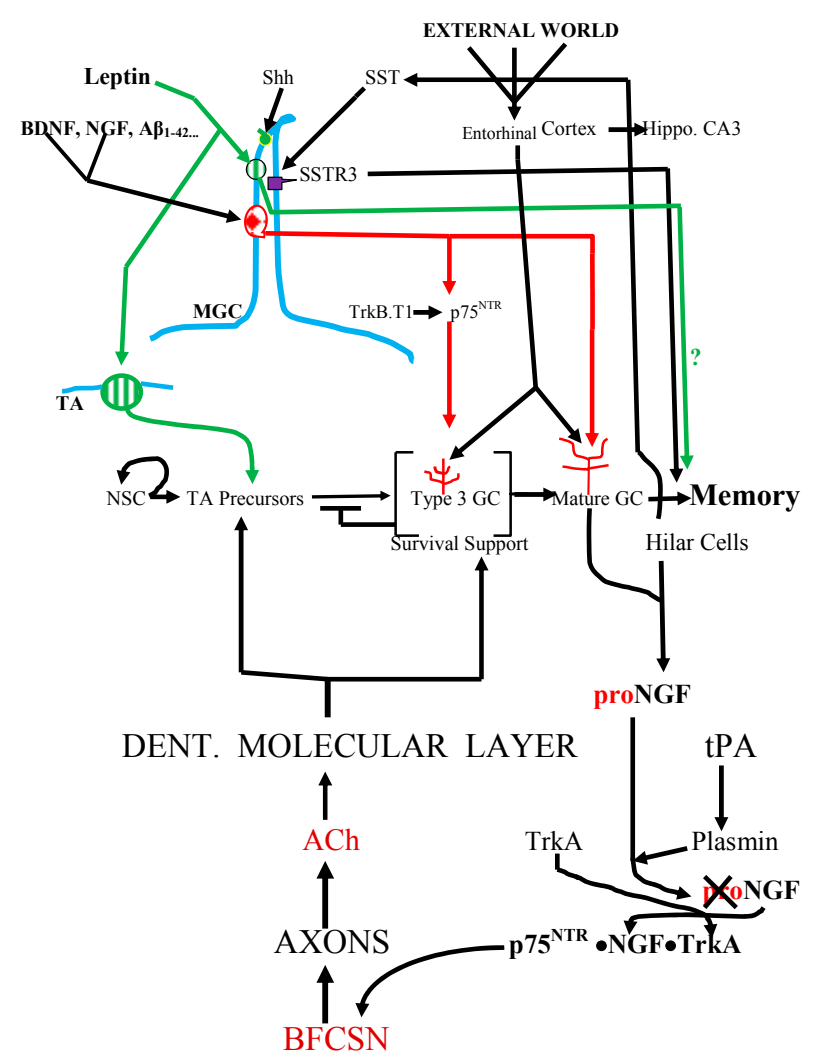

Figure 1. Receptors known to be in the cilium of a dentate granule cell. With the help of ACh (acetylcholine ) from BFCSNs (basal forebrain cholinergic septal neurons), signals from these receptors drive the progression of the progeny of rapidly proliferating initially non-ciliated TA (transit amplifying) cells from the stem cell niche in the dentate gyral SGZ (subgranular zone) to ciliated post-mitotic, mature cells in the overlying granule cell layer. There they receive data from the EC hub and separate overlapping patterns to produce retrievable distinct memories. The "tree-like" structures over the Type 3 and Mature GCs (granule cells) are dendrites. Also note that the green lines and arrows correspond to LepRb functions; red lines and arrows correspond to $\mathrm{p} 75^{\mathrm{NTR}}$ functions; blue line represents primary cilium. Please note the Type 3 GC in this Figure is Immature GC. The symbols: $\mathbb{D}$ LepRb; p $75^{\mathrm{NTR}} \square$ SSTR3.

To do this, the dentate gyrus must be strikingly different from other parts of the brain with their terminally postmitotic neurons [19,20]. Having a permanent population of neurons continuously overwriting past memory circuits would not be the kind of data receiver the owner needs to distinguish between and remember the whats, whens and wheres of similar events. The solution to this problem was to have a constantly renewing pool of hyperexcitable granule cells, each produced initially with "virgin" processes on which to record novel input before maturing, loading up with synapses and finally fading into cellular crones. Adult neurogenesis is what makes the dentate gyrus such a key part of the memory-recording machinery [9-19]. Indeed, only the young adult-born granule cells mediate pattern separation, but as they age, they switch from separating fresh overlapping input patterns to restoring past inputs [21]. However, it should be noted that while a lack of new granule cells impedes 
the formation of clearly defined memories and distinguishing between overlapping inputs, overloading granule cell networks with new granule cells overwrites and erases pre-existing memory circuits [22].

A lot of effort has been, and is being, spent trying to understand what drives adult neurogenesis and how these adult-born cells contribute to cognition from newborn stem cell daughters to neuronal crones.

\section{Granule Cells}

Adult granule cell production is maintained by a pool of stem cells, known as type 1 radial cells, housed in their special dentate gyral SGZ (subgranular zone) niche [9,19,23-26]. These type 1 cells have all the features of astrocytes [25]. From their SGZ niche, they shove their apical dendrites through the overlying tightly packed layer of mature granule cells and out into the molecular layer to monitor the activities in the neuronal neighborhood. It is likely that the stem cells and their progeny also form a tightly apposed, multicomponent but intercommunicating SGZ population, the activity within each of its subpopulations being determined by the signals from, and the density of, the contacts with the other subpopulations (Figure 1).

A stem cell resists cell cycle entry to protect its "stemness", which is the tissue's "reserve currency", an excessive expenditure of which may ultimately exhaust the supply of new granule cells. Its decision to start a clone-generating cycle depends on the overlying granule cells' NMDA receptor activity, a measure of their overall functional adequacy [26-28]. A sub-threshold overlying activity will induce the stem cells to start a cycle to make enough functioning mature cells to restore the background activity. An activated stem cell will, on the average, produce one daughter like itself and a second daughter that will keep its cell cycle engine running, leave the niche to produce the first two type 2a TA (transit amplifying) cells, the most proliferatively active of the new clone of progenitor cells [19]. These cells lose their parental radial processes, but they still have stem cell and radial glial cell markers such as glial fibrillary acidic protein and express the Sox gene to prevent precocious differentiation. These cells proliferate in clusters around the radial scaffold and capillaries to get growth and development factors such as ADP/ATP, BDNF, and VEGF [9,15,19,23,24,29]. Indeed, this availability of VEGF is why neurogenesis is tightly linked to angiogenesis in the SGZ [26].

The type 2a TA cells generate the less proliferatively active type $2 \mathrm{~b}$ cells, which by expressing the NeuroD1 gene shifts from the glial to the neuronal phenotype. These cells are also stimulated by Wnt 3a from surrounding "professional" astrocytes to switch on their Proxl gene to produce the specific dentate granule cell marker, which will continue to be needed by their mature progeny to maintain the correct gene expression pattern $[9,15]$. These type $2 b$ cells are the first of the precursors to express Tis21, the product of which will cause their progeny to become terminally post-mitotic by inhibiting cell cycle-initiating cyclin D1 transcription [30]. This TIS21 expression also marks the switch to full synaptic integration and impending glutamatergic innervations. However, the first synapses formed by the newborns are with axons from GABAergic hilar basket cells, which are not the potent inhibitory response filters for the newborns as they are for the "adult" granule cells. In fact, immature granule cells receive excitatory, instead of inhibitory, signals from GABAergic synapses as they have $\mathrm{NKCCl}$ $\left(\mathrm{Na}^{+}-\mathrm{K}^{+}-\mathrm{Cl}^{-}\right)$transporters that hyperpolarize the cells by increasing their intracellular $\mathrm{Cl}^{-}$ concentrations. Thus when GABA opens its target $\mathrm{Cl}^{-}$channels, $\mathrm{Cl}^{-}$flows out, depolarizing and exciting the cell. However, when the young type 3 granule cell is maturing, it discards the $\mathrm{NKCCl}$ 
transporter and thus has a low resting $\mathrm{Cl}^{-}$concentration. Therefore, when GABA opens its $\mathrm{Cl}^{-}$ channels, $\mathrm{Cl}^{-}$flows into the cell to hyperpolarize and inhibit it [31].

"Infant mortality" in the SGZ is normally high. About $50 \%$ of the newborns may die without reaching the granule cell layer and, as in most such systems, the signals from the surviving fraction probably feed back to determine the stem cell/TA production level. However, this mortality can be reduced by NGF produced in the dentate gyrus from proNGF by the pro-domain removing tPA (plasminogen activator)-activated plasmin. This "mature", i.e., "pro-less", NGF forms p $75^{\mathrm{NTR}}$.NGF-TrkA complexes that are carried up the axon and stimulate the distant BFCSNs (basal forebrain cholinergic septal neurons) to make and secrete ACh that promotes newborn granule cell survival [32,33] (Figure 1).

The surviving type 3 progeny of the type $2 \mathrm{~b}$ cells are migratory neuroblasts. They move up into the lower third of the granule cell layer where they will stay and complete their maturation into functional ciliated granule cells. They must now become part of the dentate gyral ANTs (functionally integrated astrocyte-neuron teams) hill [34]. The incoming granule cells extend their newly formed, "clean-slate" dendrites through the upper granular layer and into the molecular layer and in the process cause the pre-existing astrocytes to reconfigure their structure to form close functional contacts with the arriving dendritic spines and synapses [34]. Now the new granule cells start learning about the outside world as they synapse with the axons from the EC hub (Figure 1).

\section{Involvement of the Granule Cell's Primary Cilium in Adult Neurogenesis}

We have known since 1963 that mature dentate granule cells have a non-motile, $\sim 4-\mu \mathrm{m}$ primary cilium [35-40]. However, when do they get this antenna? According to Kumamoto et al. [41], the early type 2 a TA neuroblasts do not have cilia. Indeed that would be expected because the ciliumforming mother centriole and the cytoskeleton are otherwise occupied during rapid cell cycling and any pre-existing cilia are deacetylated and retracted by HDAC6 (histone deacetylase 6). They showed this with specifically marked retroviruses to label the proliferating progenitors and follow their development. Moreover, as expected, they found that the progeny of the proliferating progenitors started producing cilia only after they had stopped proliferating (i.e., in stage 3) and were inserting themselves into the mature granule cell layer and pushing their new dendrites through the layer of mature granule cells to meet the glutamatergic axons from the EC (Figure 1). At first sight, this means that preventing cilium formation should prevent migration and maturation but not TA cell proliferation. However, according to Amador-Arjona et al. [42] when SGZ cells were deprived of cilia by conditionally turning off their Ift20 (intraflagellar transport 20 gene [43]), there was a 50\% drop in SGZ proliferative activity indicated by a declining fraction of $\mathrm{DCX}^{+}, \mathrm{BrdU}^{+}, \mathrm{Ki}^{+}$, and $\mathrm{PCNA}^{+}$ cycling cells. Since only TA neuroblasts were affected, does this mean that TA cells are ciliated? Not necessarily, because this reduced proliferation was more likely to increase inhibitory "pressure" on the non-ciliated TA subpopulation from the build-up of deciliated newborns that could not leave the SGZ (Figure 1). Regardless of how the deciliation reduced neurogenesis, it partially impaired novelty recognition and the detection of the escape hole in a Barnes maze [42]. More recently, Berbari et al. [36] have also reported that deciliating the murine dentate gyrus and the hippocampal CA1 field by deleting 
the IFT88 gene [43] resulted in impaired aversive learning and memory and novel object recognition. Thus, dentate granule cells must have cilia to do their memory recording jobs.

\section{Looking into the Dentate Granule Cell's Cilium}

It has been known for $\sim 10$ years that the murine mature granule cell cilium houses Shh (sonic hedgehog) machinery [44,45] (Figure 1). Indeed Goetz et al. [46] have called the primary cilium a "hedgehog transduction machine". In addition, Breunig et al. [47] and Han et al. [45] have shown that primary cilia regulate adult neurogenesis via Shh signaling.

Then there is the pan-neurotrophin $\mathrm{p} 75^{\mathrm{NTR}}$ receptor in the cilium which can be activated by BDNF, NGF, NT-3, NT4/5, TrkA, TrkB and, as we shall see later, even by the oligomeric A $\beta$ drivers of Alzheimer's neuropathology $[37,38,48,49]$ (Figures 1 and 2). The localization of $\mathrm{p} 75^{\mathrm{NTR}}$ to the dentate gyral granule cells' cilia was surprising. It was widely believed that any $\mathrm{p} 75^{\mathrm{NTR}}$ in the dentate gyrus must be in the axons of BFCNs neurons that have been lured to granule cell dendrites in the inner molecular layer to bind to factors such as NGF from granule cells and hilar neurons [32,50,51] (Figure 1). The BFCNs p $75^{\text {NTR }}$ would combine with TrkA and NGF (derived from proNGF by TPA-plasmin) to form the

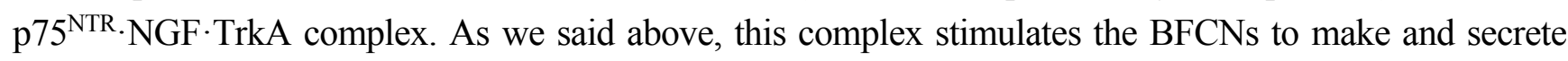
$\mathrm{ACh}$, which promotes the proliferation, survival, and maturation of newborn cells [32,33] (Figure 1).
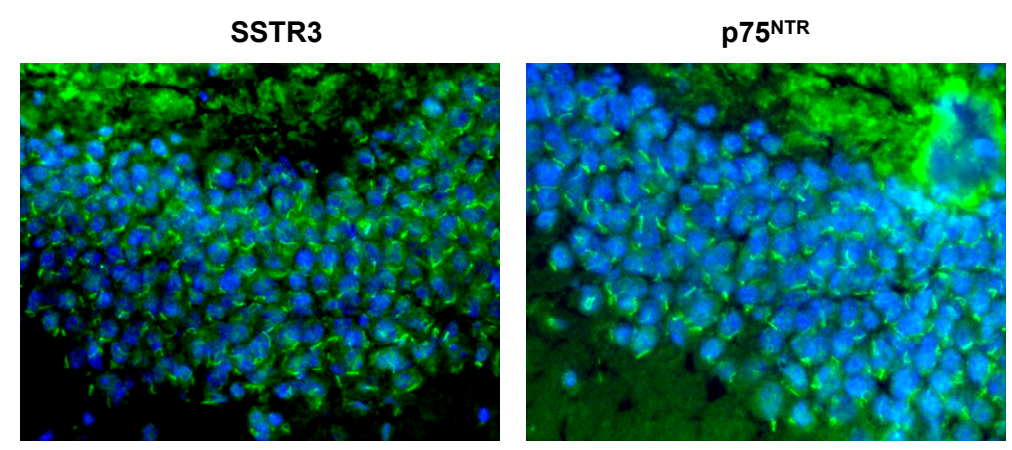

Figure 2. The ciliary localization of $p 75^{\mathrm{NTR}}$ and SSTR3 in the mature murine dentate granule cells. The identity of the localization of $\mathrm{p} 75^{\mathrm{NTR}}$ with that of cilium-specific SSTR3 establishes $\mathrm{p} 75^{\mathrm{NTR}}$, s ciliary localization. The anti-p $75^{\mathrm{NTR}}$ and SSTR3 antibodies and the methodology used to immunostain these cells have been described in [37,38,51].

So one of $\mathrm{p} 75^{\mathrm{NTR}}$, $\mathrm{s}$ non-ciliary actions is to drive adult neurogenesis. However, what might ciliary p $75^{\text {NTR }}$ do? Proliferating (i.e., BrdU-labeled) SGZ cells seem to express $\mathrm{p} 75^{\mathrm{NTR}}$ and knocking out the $\mathrm{p} 75^{\mathrm{NTR}}$ gene reduces the proliferating cells and adult neurogenesis by $59 \%-79 \%$ [52-54]. However, the proliferatively competent TA cells do not have cilia according to Kumamoto et al. [41]. Instead, as we will see in the next paragraph the maturing granule cells' migration and maturation-stimulating ciliary $\mathrm{p} 75^{\mathrm{NTR}}$ might indirectly determine TA cell proliferation via the SGZ type 3 cell population density and feedback "pressure". However, any interference with $\mathrm{p} 75^{\mathrm{NTR}}$ gene expression and function would also impede the production by BFCNs of the proliferogenic and survival-promoting ACh (Figure 1).

The most important function of ciliary $\mathrm{p} 75^{\mathrm{NTR}}$ is suggested by the fact that it is the mature granule cells that have the ciliary $\mathrm{p} 75^{\mathrm{NTR}}$ (Figure 2 ). What could these mature granule cells be doing with their ciliary $\mathrm{p} 75^{\mathrm{NTR}}$ ? A possible answer to this is suggested by the observation of Kumamoto et al. [41] that 
post-mitotic type 3 newborn granule cells use their cilia to produce dendrites, start migrating upward and connect to the EC axons (Figure 1). Non-liganded signals from ciliary $\mathrm{p} 75^{\mathrm{NTR}}$ complexed with those from TrkB T1 (truncated TrkB) could drive the outgrowth of the immature granule cell's dendritogenic filopodia [55-57] (Figure 1). Another participant in arborization might be ceramide, which promotes ciliogenesis and process formation by preventing microtubule deacetylation and retraction via HDAC6 inhibition [58,59]. Ceramide is part of the ring-shaped pericentriolar compartment known as "the sphingosome" that is attached to the ciliary basal body where it functions in ciliogenesis and cell migration. Moreover, it has been appropriately shown to promote dendrite arborization in cultured rat embryonic hippocampal neurons [60,61]. The linkage of ceramide to ciliary $\mathrm{p} 75^{\mathrm{NTR}}$ is indicated by the fact that NGF-activated $\mathrm{p} 75^{\mathrm{NTR}}$ stimulates the ceramide-producing membrane-associated sphingomyelinase [62]. Thus, signaling from liganded and non-liganded ciliary $\mathrm{p} 75^{\mathrm{NTR}}$ may indeed drive the ciliogenesis, dendritic arborization, and the exit of newborn cells from the SGZ into the mature granule cell layer indicated by the observations of Kumamoto et al. [41]. In addition, the new mature granule cells may retain their ciliary $\mathrm{p} 75^{\mathrm{NTR}}$ to maintain their cilia and modulate their dendritic arbors.

Another receptor in the mature granule cell's cilium is the non-proliferogenic, GPCR-coupled SSTR3 (somatostatin receptor 3) [37-40,63-65] (Figure 2). Unlike the other four SSTRs (i.e., SSTRs $1,2,4$, and 5), SSTR3 is confined to primary cilia by a specific cilium-targeting amino acid sequence in its third intracellular loop, i.e., the I3-CTS [63]. Therefore, it is important for what follows in the next section that if a cell produces something that co-localizes to a protruding $\sim 4-\mu \mathrm{m}$ structure along with SSTR3, that protruding structure is a cilium and that something must also be ciliary.

Stanić et al. [40] have found that newborn neuroblasts do not put SSTR3 into their cilia, but the postmitotic mature granule cells in the granule cell layer, such as those in Figure 2, have loaded it into their cilia at a later stage of their development. Obviously, they put it into their cilia to do a "mature" job related to cognition. That job is memory encoding because without it, mice cannot recognize novel objects [64]. In addition, a lack of SSTR3 could be at least partially responsible for the cognitive deficit caused by granule cell deciliation recently reported by Berbari et al. [63].

Since adult-born granule cells do not have cilia until the type 3 stage [41], we will suggest below that a SSTR3-like delayed cilium loading may also apply to LepRb (Figure 1).

\section{The Ciliary Leptin Receptor in Adult Neurogenesis and AD}

As we said in the Introduction, there is evidence for an involvement of leptin and its functional LepRb receptor in memory formation and possibly reducing the core drivers of Alzheimer's disease (AD), a very important possibility for our growing population of seniors.

The common (>95\%) form of AD, LOAD (i.e., late onset AD) or Sporadic AD starts its initially unnoticed, decades-long journey through the brain from its "Ground Zero" in the lateral EC [66]. From there it spreads through existing neural circuitry, leaving disconnected networks, an atrophic hippocampus, and eventually a noticeably declining cognition in its wake [67].

The accumulating primary drivers of the slowly advancing pathology perhaps decades before the appearance of symptoms seem to be A $\beta O s$ (A $\beta_{42}$ peptide oligomers) [68-70] (Figure 3). Active neurons in healthy young brains produce physiologically functioning and non-toxic $A \beta_{42}$ 
monomers via the sequential actions of BACE1 (beta-site amyloid precursor protein-cleaving enzyme 1) and $\gamma$-secretases that chop the A $\beta_{42}$ off APP (amyloid- $\beta$ precursor protein) (Figure 3 ). The resulting pieces are packaged into vesicles, transported down axons to their terminals, from which they are released during synaptic activity [71,72]. In the young brain, the cellular levels of the $A \beta 42$ monomers and its variously processed and potentially dangerous derivatives are kept at a safe picomolar level by several proteases, such as neprilysin, as well as by ejection from the brain by LRP1 (low density lipoprotein receptor-related protein 1), the potent $A \beta_{42}$ efflux driver [73]. However, with advancing age, declining disposal mechanisms enable the levels of $A \beta_{1-42}$ peptides and their toxic derivatives and configurations to climb into the danger zone and start making "cocktails" of dynamically toxic A $\beta O s$, the TOCs (toxic oligomeric "cocktails") in Figure $3[68,70,74]$. One of the reasons for the excessive buildup of the $\mathrm{A} \beta \mathrm{O}$ s-forming $\mathrm{A} \beta_{42}$ is the loss, early in the spread of $\mathrm{AD}$ pathology, of the production of the neprilysin-promoting SST (somatostatin) by SST-producing cells in the dentate gyral hilus and the hippocampal CA1-CA3 fields [75,76] (Figure 3).

Another consequence of the $A \beta_{42}$ buildup is an increased expression of the $\mathrm{p} 75^{\mathrm{NTR}}$ pan-neurotrophin receptor as demonstrated in both cultured SH-SY5Y human neuroblasts and hippocampal membranes from $\mathrm{AD}$ patients $[37,38,51,77]$. However, it is unlikely that the mature dentate granule cells' ciliary p $75^{\text {NTR }}$ contributes to this rise and its consequences because we have observed that these cilia are significantly shortened (e.g., from 4- to 2.2- $\mu \mathrm{m} ; p<0.001$ ) in 3xTg AD mice [37] (Figures 3 and 4). However, increased non-ciliary $\mathrm{p} 75^{\mathrm{NTR}}$ in other hippocampal fields, such as CA1, and its stimulation by $\mathrm{A} \beta 42[48,49]$ combines with drops in TrkA and tPA to form a toxic $\mathrm{p} 75^{\mathrm{NTR}}$. Sortilin proNGF complex instead of the normal $75^{\mathrm{NTR}}$.NGF-TrkA complex [32,78] (Figures 1 and 3). The p $75^{\text {NTR }}$. Sortilin $\cdot$ proNGF complex kills BFCSN cells and with them their adult neurogenesis-promoting ACh secretion [32] (Figure 3).

Since adult neurogenesis normally drops with age in humans and rodents [13], it presumably should drop faster with the surging A $\beta O s$. Nevertheless, the increased mortality of newborn cells might feed-back and stimulate NSC and the non-ciliated TA cells (Figure 3). Moreover, there are indeed reports of increased proliferation in the early AD stages [79-81]. However, despite this, neurogenesis drops because the newborn neurons neither survive nor mature. This happens in part because of the action of pTAU, the other toxic and self-inducing AD driver, and in part owing to the lack of ACh due to the destruction of BFCSNs by the $\mathrm{p} 75^{\mathrm{NTR}}$. Sortilin proNGF complex (Figure 3). Moreover, over time the drop in neurogenesis and declining mature cell population, perhaps because of excessive, apoptogenic ciliary $\mathrm{p} 75^{\mathrm{NTR}}$ activation, reflexively activates stem and TA cell proliferation and consequently depletes the stem cell pool [79,81] (Figure 3).

$\mathrm{A} \beta_{42}$ is a triply dangerous peptide. Besides forming the toxic $\mathrm{A} \beta \mathrm{Os}$, it is a self-inducing pathology "seed" and a transcription factor! Either exogenous or endogenous $A \beta_{42}$ peptides can enter the nuclei of both astrocytes and neurons and promote their own endogenous production by activating the genes for the APP precursor and the BACE1 protease [82,83] (Figure 3). This increases $A \beta_{42} / A \beta O$ s secretion and spreading, reciprocal recruitment of the astrocyte-neuron members of the brain's ANTs [84]. But as we said above, A $\beta O$ s are not alone. As Ittner and Götz [85] have said, A $\beta 42$ and p-TAU form a toxic "pas de deux" (two-step) or, to over-paraphrase Bloom [86], $\mathrm{A} \beta_{42}$ is the $\mathrm{AD}$ gun and hyperphosphorylated TAUes are its bullets. 


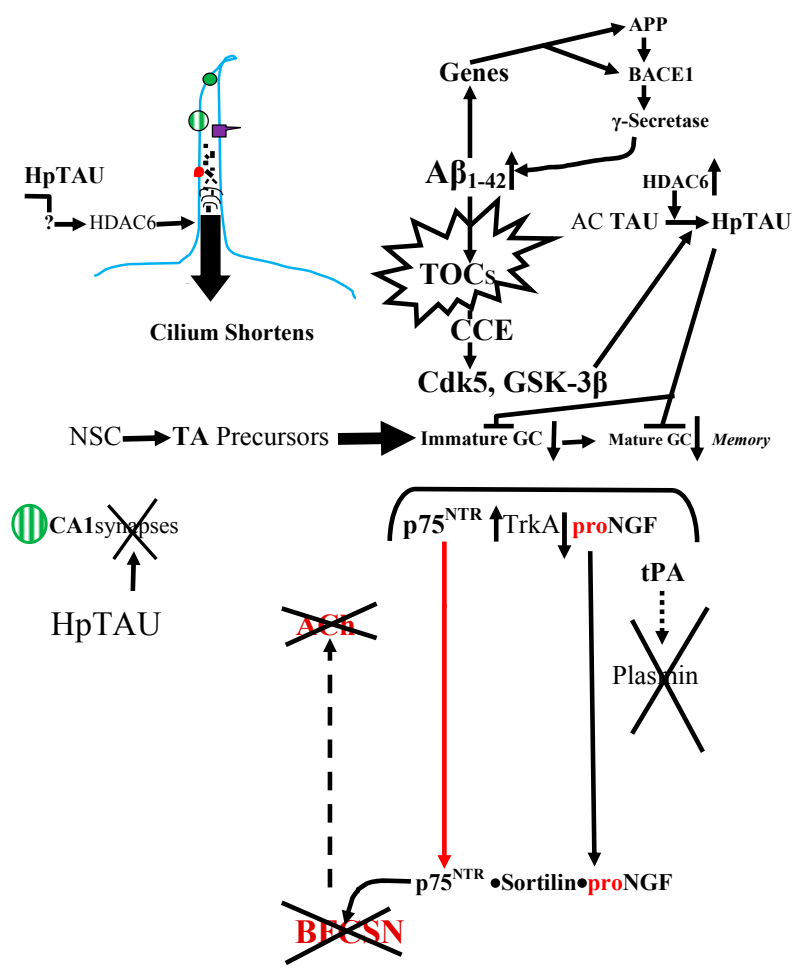

Figure 3. Some possible interactions between the dentate gyral granule cells' ciliary receptors, $A \beta O$ s (toxic oligomeric $A \beta_{1-42}$ ) and toxic hyperphosphorylated TAU (Hp-TAU in the Figure and pTAU in the text) that together drive the spread of Alzheimer's neuropathology from the EC to interconnected brain regions. As illustrated here, in the core of $\mathrm{AD}$ pathology are accumulating $\mathrm{A} \beta_{42}$ monomers that aggregate into configurationally dynamic toxic oligomeric "cocktails" (TOCs), which produce a cascade of protein kinases that generate the similarly self-inducing toxic pTAU by several ways. At first AC-TAU (acetylated TAU) resists hyperphosphorylation and aggregation, but the level of HDAC6 (histone deacetylase 6) rises in the AD brain and deacetylates TAU, which can then be hyperphosphorylated. One of the ways pTAU is made is by triggering CCE (cell cycle re-entry) of supposed terminally post-mitotic neurons that cannot enter prophase but still activate $\mathrm{Cdk} 1$-cyclin $\mathrm{B} 1$ mitotic kinase, eject $\mathrm{Cdk} 5$ from their nuclei into the cytoplasm, and activate the key cytoplasmic GSK-3 $\beta$ where they produce the toxic pTAU instead of initiating prophase. As explained in the text, the newborn granule cells no longer have the survival support of ACh and they also face the self-inducing toxic pTAU produced by the similarly self-inducing A $\beta O$ s. The reduced neurogenesis in the slowly atrophying hippocampal structure signals stem cells to generate TA cells to replace lost cells but this is a futile effort because of the high mortality of their progeny. In addition, pTAU causes granule cells' cilia to shrink, which might reduce the arborization, maturation, and migration-driving signaling from the $\mathrm{p} 75^{\mathrm{NTR}}$ receptor. Note: $\mathrm{pTAU}$ is Hp-TAU in the figure to emphasize the hyperphosphorylation of the peptide. NSC: Neural stem cells. The green lines and arrows correspond to LepRb functions; red lines and arrows correspond to $\mathrm{p} 75^{\mathrm{NTR}}$ functions; blue line represents primary cilium. The symbols: (ID)

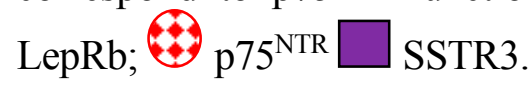


$\underline{A}$

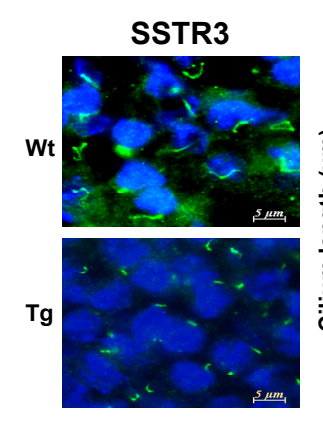

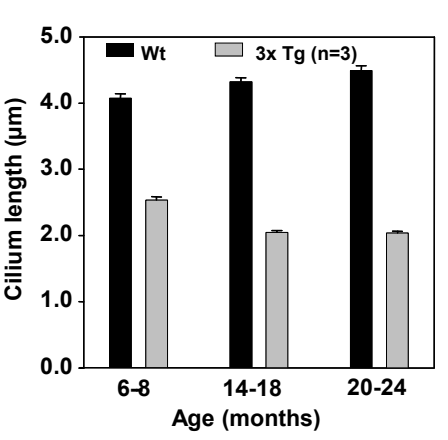

B

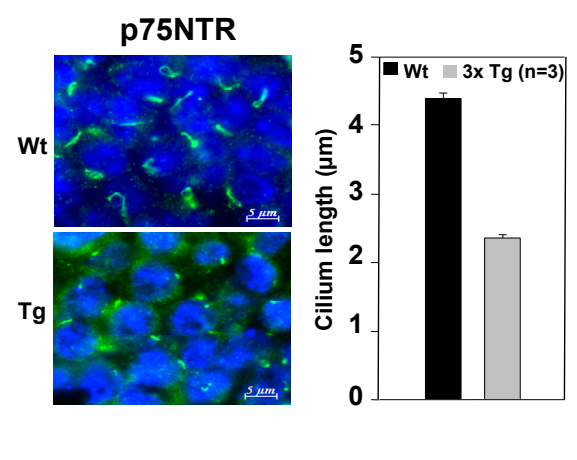

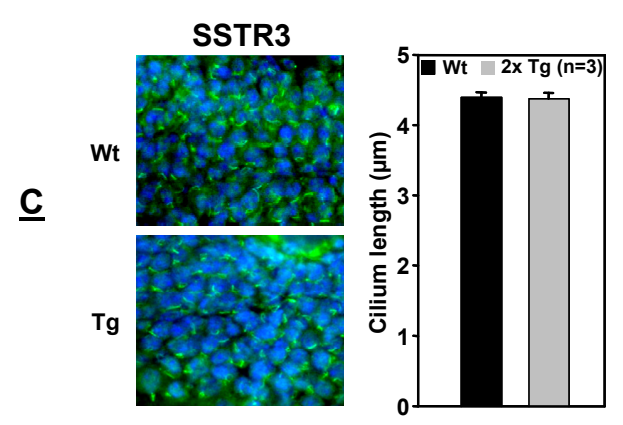

Figure 4. A ciliary example of the toxic A $\beta_{42} /$ pTAU "two-step" of Ittner and Götz [85]. (A): Accumulating $A \beta_{1-42}$ alone in $2 x$ AD-transgenic mice does not affect the length of granule cilia. (B) and (C): But the length of granule cells' cilia is shorter in $3 \times$ AD-transgenic mice accumulating $A \beta_{1-42}$ and expressing a human mutant Tau when immunostained with SSTR3 and p $75^{\text {NTR }}$ antibodies. It is likely, as shown in Figure 3, that the shortening is due to pTAU-promoted tubulin deacetylation and the resulting fragmentation of the microtubular axoneme by HDAC6 [58,87,88]. The experimental details may be found in Chakravarthy et al. [37].

The granule cell cilia provide an example of the toxic collaboration of the two AD drivers. These cilia are unaffected in $2 x T g-A D$ mice which only accumulate $A \beta_{42}$ (Figure 4), but they are significantly shorter in $3 x T g-A D$ mice which accumulate $A \beta_{42}$ and express human mutant Tau (Figure 4) [37]. A clue to the cause of this Tau-dependant shortening is the reduced tubulin acetylation and significantly elevated HDAC6 deacetylase in the cortices and hippocampi of human AD brains [87]. This cilial shortening may be due to HDAC6 deacetylating and thereby fragmenting the ciliary axonemal microtubules $[58,87,88]$ (Figure 3 ).

One-way $\mathrm{A} \beta \mathrm{O}$ might induce the $\mathrm{AD}$ gun is to induce extrasynaptic NMDA receptors to let $\mathrm{Ca}^{2+}$ surge into the neurons. This activates AMPK, CAMKII and GSK-3 $\beta$, which phosphorylate several Tau residues $[69,89]$ (Figure 3). This reconfigures Tau to prevent it from working with kinesin motors to carry cargo to the axon terminus [89-91]. Instead of staying in the axon pTAU ectopically redistributes to the soma, dendrites, and synapses [86,92]. pTAU becomes a potent network disruptor by forming a complex with the Fyn tyrosine kinase. The A $\beta O$ s start this by binding to the normal prion protein $\left(\mathrm{PrP}^{\mathrm{C}}\right)$ in the postsynaptic plasma membrane [90]. This activates $F y n$, which phosphorylates Tau tyrosine residues and binds to pTAU. The resulting Fyn p pTAU complex then invades dendritic spines where it targets and phosphorylates NMDA receptors and induces them to admit a flood of $\mathrm{Ca}^{2+}$ that 
destroys synapses and with them the postsynaptic machinery [86,92,93] (Figure 3). With this, the toxic pTAU is released in exosomes and spreads the neuropathology to its contacts [93].

However, there is another way to hyperphosphorylate Tau, which we have chosen to illustrate in Figure 3. Even before a person has reached the MCI (mild cognitive impairment) stage of the disease, $\mathrm{A} \beta \mathrm{O}$ s have caused a large number of supposedly terminally post-mitotic neurons to overexpress MiRNA-26b. This RNA species downregulates the Rb (retinoblastoma) protein that is part of a cell cycle genes-associated complex consisting of $\mathrm{Rb} \cdot \mathrm{E} 2 \mathrm{~F} \cdot \mathrm{Cdk} 5$, which has been preventing CCE (cell cycle re-entry) by blocking the expression of major cell cycle proteins [94]. MiRNA-26b over-expression and $\mathrm{Rb}$ downregulation result in the dispersal of the genes-blocking complex, which starts a series of events leading to DNA replication. Indeed, the cell may finish replicating its chromosomes but it cannot initiate mitosis [94,95]. Nevertheless, it still expresses the Cdk1-cyclin B1 mitotic kinase, which in a normal cell would be activated and promptly sent into the nucleus to trigger nuclear membrane breakdown and chromosome condensation. However, in a CCE neuron it stays in the cytoplasm, where it can access and phosphorylate Tau [95]. However, much before this, the MiRNA-26b-triggered dispersal of the nuclear CCE-blocking Rb·E2F·Cdk5 complex releases the Cdk5 kinase which enters the cytoplasm where it can also access and phosphorylate Tau and phosphorylate and inactivate any available $\mathrm{Rb}$ [94].

Thus, infectious A $\beta O$ s have various ways to the produce their pTAU "bullets" and with them spread $\mathrm{AD}$ pathology. The messages from all of this are clear: $\mathrm{A} \beta \mathrm{O}$ s are at the heart of $\mathrm{AD}$ pathology and to attenuate $\mathrm{AD}$ pathology you must stop the production of TOCs and their induction of pTAU bullets.

\section{Leptin Reduces Aßs Production}

It seems likely from experiments on $\mathrm{AD}$-model transgenic mice as well as rats that leptin/LepRb might also be able to hit the source of the AD drivers in humans [6,96-98]. As we have seen, the primary drivers of $\mathrm{AD}$ pathology most likely are the $\mathrm{A} \beta \mathrm{O}$ s. As shown in Figure 3, $\mathrm{A} \beta 42$, the non-toxic source of the toxic ABOs, is cut out of the APP precursor by BACE1 and $\gamma$-secretase. Leptin strikes at AD pathology by reducing $A \beta_{1-42}$ production via a SIRT1 (histone deacetylase)-mediated reduction of BACE1 expression [99] (Figure 5). Moreover, besides reducing A $\beta O s$, leptin decreases the production of the synapse-destroying pTAU by inhibiting a principal Tau kinase, GSK-3 $\beta$ [96] (Figure 5). By reducing $A \beta_{1-42}$ production, leptin also prevents the destructive surging of caspase 3 in synapses and thus the decline in synaptic density in the CA1 field and the associated hippocampus-related memory deficits [100] (Figure 5). However, what does leptin do to adult neurogenesis? Garza et al. [101] found that 14 days of intermittent intraperitoneal injections of leptin $(1.0 \mathrm{mg} / \mathrm{kg})$ into adult $\mathrm{C} 5 \mathrm{BL} / 6 \mathrm{~J}$ mice significantly stimulated proliferation in the animals' SGZs without affecting differentiation or survival of the newborn cells (Figure 1). Leptin also stimulated the STAT3/PI3k/Akt-mediated proliferation of cultured adult dentate progenitor cells. They later reported that intraperitoneal leptin injections into male Sprague-Dawley rats also overcame the glucocorticoid inhibition of adult neurogenesis possibly by stimulating BDNF expression [102]. 


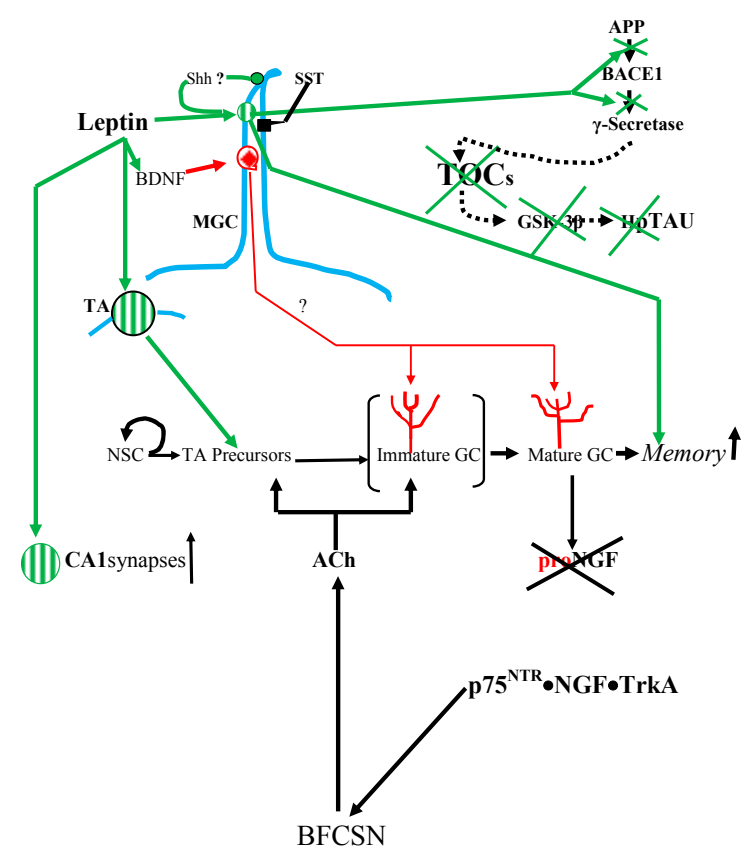

Figure 5. This figure, based on the mechanisms discussed in the text, describes how leptin-induced signaling by preciliary and ciliary LepRb in dentate granule cells and non-ciliary synaptic LepRb in hippocampal CA1 neurons might reduce the AD-induced loss of memory by attenuating or preventing the production of the toxic TOCs and pTAU in Figure 3 . The green lines and arrows correspond to LepRb functions; red lines and arrows correspond to $\mathrm{p} 75^{\mathrm{NTR}}$ functions; blue line represents primary cilium. The symbols: $\mathbb{D}$ LepRb; $75^{\mathrm{NTR}} \square$ SSTR3.

Obviously, it would have been less traumatic than intraperitoneal injections to continuously and endogenously administer leptin. In addition, Pérez-González et al. [103] were able to do this elegantly. They produced a stable, elevated intracerebral level of leptin by injecting a HIV-Leptin gene-carrying lentiviral vector into the lateral cerebral ventricles of APP/PS1 AD-model transgenic mice. During the following 3 months, the implanted, virally vectored leptin gene activity had stimulated dentate gyral progenitor proliferation and attenuated $\mathrm{A} \beta \mathrm{s}$-induced neurodegeneration.

\section{Where Do Dentate Granule Cells Put their LepRb?}

Because leptin stimulates adult neurogenesis by increasing progenitor proliferation but not maturation, we suspected that it might have been working through cilia, which, with their Shh machinery, have been shown to be involved in adult neurogenesis [42-45,47,104].

As comprehensively reviewed in [6], Harvey et al. have focused on leptin/LepRb's ability to target activities in the hippocampal CA1 field. However, CA1 is not an adult neurogenesis site. Nevertheless, they cultured rat CA1 pyramidal neurons and found LepRb punctately distributed in cytoplasm, plasma membrane, and most importantly in synapses, but not in cilia (see Figure 6 of Shanley et al. [105]). Leptin stimulates transmission at CA1 synapses and induces LTP in slices of adult CA1 tissue by increasing AMPA receptor trafficking and synaptic strength. Garza et al. [101], on the other hand, focused on the murine dentate gyrus and its SGZ. They, like Shanley et al. [105], immunostained cultured neurons for LepRb (their Figure 4B). Here too LepRb was not ciliary. They also found the same 
immunostainable punctuate cytoplasmic and perinuclear LepRb granules as did Shanley et al. [105]. Indeed, we have found the same distribution of immunostainable LepRb granules in cultured, leptinresponsive SH-SY5Y human neuroblasts (Figure 6). As can be seen, these human neuroblasts were ciliated and at least some had even put $\mathrm{p} 75^{\mathrm{NTR}}$ into their cilia like the mature murine dentate granule cells, but again LepRb was still not ciliary. [106,107]

From these examples, it would seem that LepRb is not ciliary. However, in these cases the localization may have been affected by cellular age and other factors. In our hands, using the same C57/BL6 strain of mice from the same place (Jackson Laboratories, Bar Harbor, Me) as Garza et al. [101] the in vivo mature granule cells seemingly confined LepR to their cilia (Figure 7). There were no clusters of immunostainable granules like those that we found in the proliferating SH-SY5Y neuroblasts (Figure 6). As shown in Figure 7, the granule cells' LepRb-containing "protrusions" also contained $\mathrm{p} 75^{\mathrm{NTR}}$, which we have proven to be confined to mature granule cell cilia [37,38]. Even more convincing, they also contained SSTR3, which specifically binds only to cilia with its APSQ ciliary localization amino acid sequence [63].

A
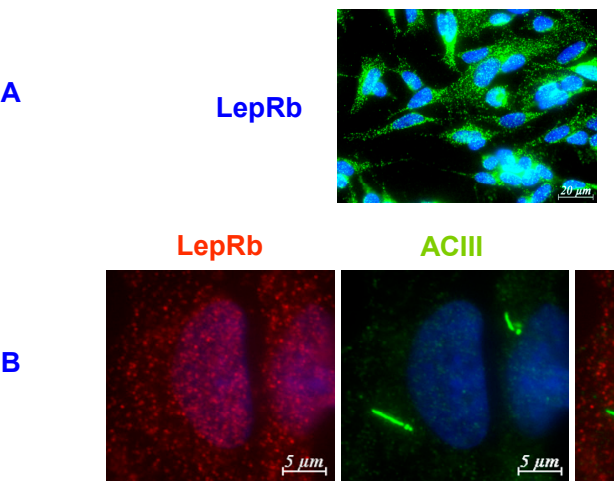

p75 NTR

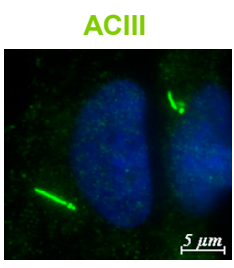

$\mathrm{ACIII}$
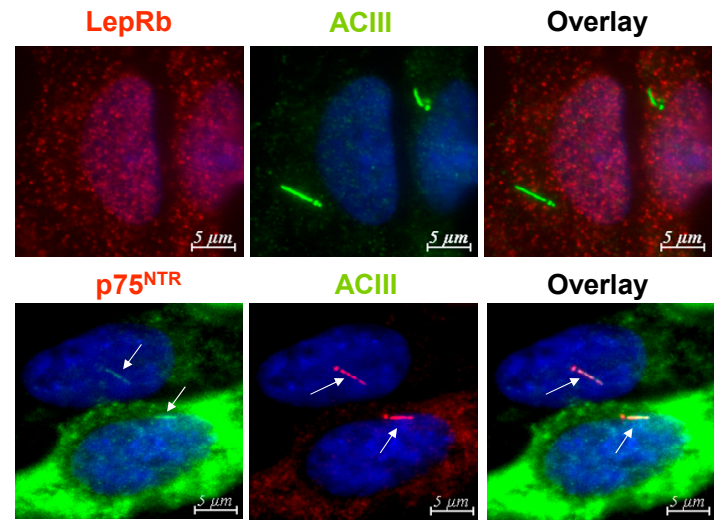

Overlay

C

Figure 6. (A). An example of the immunostainable non-ciliary punctate distribution of LepRb in human SH-SY5Y neuroblastoma cells that is like the non-ciliary punctate LepRb distributions in cultured rat CA1 and cultured murine dentate granule cells [101,105]. (B). These neuroblastoma cells do not have the cilium-specific SSTR3, but they have the cilium-specific ACIII (adenylyl cyclase III). Here we see that the immunostained Lep Rb particulates are not ciliary, i.e., are not co-localized with ACIII. It should be noted that Greco et al. [108] have shown, and we have confirmed (data not shown), that these neuroblasts are leptin responsive. C. It should also be noted that the cilia of the non-cycling SH-SY5Y cells in these cultures did contain $\mathrm{p} 75^{\mathrm{NTR}}$ (immunostained as described in $[37,38,51])$, which would be consistent with the ability of the $\mathrm{p} 75^{\mathrm{NTR}}$-induced ceramide production to drive cilium formation [58-61]. The cells were cultured as described by Chakravarthy et al. [109] and the anti-LepRb monoclonal $\mathrm{IgG}_{1}$ antibody (Ob-R, B-3, and sc8391) was purchased from Santa Cruz Biotechnology Inc. (CA). Polyclonal anti-ACIII antibody (C-20, sc-588) was also purchased from Santa Cruz Biotechnology. 


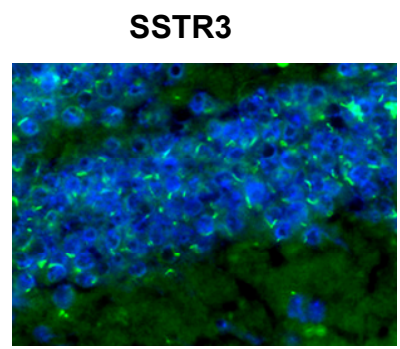

SSTR3

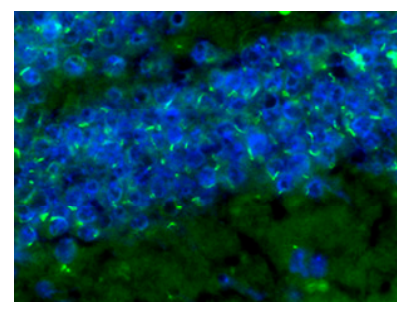

p75 ${ }^{\text {NTR }}$

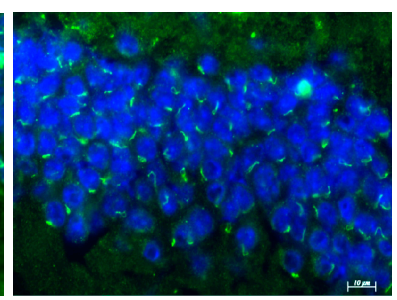

LepRb

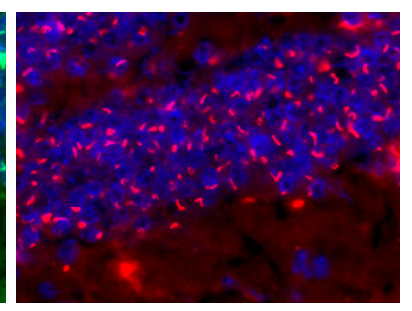

LepRb

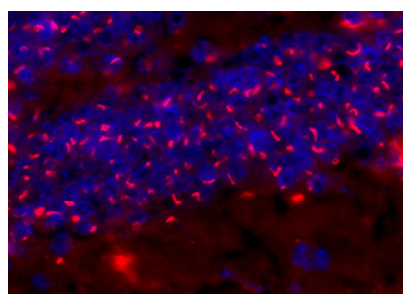

Overlay

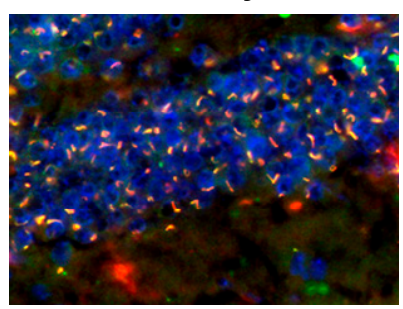

Figure 7. LepRb is detectably localized only to the primary cilia of mature murine dentate granule cells along with $\mathrm{p} 75^{\mathrm{NTR}}$ and SSTR3 receptors. Hemi-brains from 7-8 months-old female wild-type C57BL6 mice were immunostained with LepRb, p75 ${ }^{\mathrm{NTR}}$, or SSTR3 antibody as described in Figures 2 and 6 and in [37,38,51]. Similar results were obtained with three 14-18 months-old female mice and one male mouse. When co-immunostained with LepRb monoclonal antibody and either SSTR3 or $\mathrm{p} 75^{\mathrm{NTR}}$ polyclonal antibody, the signals from the LepRb and SSTR3 or $\mathrm{p} 75^{\mathrm{NTR}}$ (data not shown) antibody merged (overlay) indicating ciliary co-localization. In all immunohistochemical studies, Dako fluorescent mounting medium containing DAPI DNA-binding nuclear stain was used and the tissue sections were examined with an Olympus fluorescence microscope as described in $[37,38]$. A similar demonstration of ciliary LepRB will also appear in Whitfield et al. [110].

How might this differently localized LepRb affect the leptin-induced signaling pathway in cultured and in vivo neurons? According to Garza et al. [102], the LepRb signal in the cultured granule cells follows the JAK2/STAT3/PI3K/Akt pathway as it does in the other cultured neurons. However, does this apply to the ciliary LepRb's signal pathway, especially since the cilium is loaded with the proliferogenic Shh signal transduction mechanism needed for adult neurogenesis [45,47] (Figure 1)? How might these pathways be linked in the SGZ newborns? A clue is provided by the incompatibility of cell cycling and ciliation. As expected, the rapidly proliferating TA cells do not have cilia [41]. Instead, it is their non-proliferating, type 3 progeny that produce cilia when they start extruding processes and migrating upward into the mature granule cell layer. So it is likely that at this early stage the LepRB is still in the cell membrane, from which leptin stimulates their proliferation (Figures 1 and 4). Thus, when these cells are cultured they would only have the punctate distribution of pre-ciliary LeptRb reported by Garza et al. [101] and in the leptin-stimulable (data not shown) SH-SY5Y neuroblasts in Figure 6.

This also suggests that the dentate granule cells only load LepRb into their cilia after they start maturing. This is similar to the later ciliary loading of SSTR3 reported by Stanić et al. [40]. Thus ciliary LepRb may also be involved in a mature granule cell function such as memory encoding like SSTR3 [36,64] Figure 1. 


\section{Conclusions}

From the aforesaid it follows that recording information about the outside world streaming in from the EC hub and preventing any partially overlapping data from palimpsesting on recipient networks is the job of the very special, adult-born dentate granule cell (at least in mice). Such cells are equipped with ciliary receptor proteinsincluding leptin's LepRb receptor, the pan-neurotrophin $\mathrm{p} 75^{\mathrm{NTR}}$ receptor and the SSTR3 receptor. As summarized in Figure 1, it appears that newborn TA neurons may first use non-ciliary LepRb signaling to stimulate their proliferation. Then the TA cells' progeny use their ciliary $\mathrm{p} 75^{\mathrm{NTR}}$ to drive the production of CA3 field-connecting mossy axons and EC-connecting dendrites and migration from the SGZ to the mature dentate granule cell layer. Then as they settle in to their final "home", they load SSTR3 and LepRb into their cilia to start recording memories.

These are exciting questions for future studies. However, these are really just some possible functions of dentate granule cell's cilium. There is likely to be more than the three potent receptor/drivers that we have been discussing. We have a long way to go to understand how the granule cells use their ciliary tools to drive adult neurogenesis, encode memories and attenuate $\mathrm{AD}$-like pathology in transgenic mice. Most importantly, it is important to find out whether LepRb signaling is an AD therapeutic or more likely an AD preventative for humans. It is unlikely that signals from dispersed or ciliary LepRb can repair damage already inflicted by toxic A $\beta O$ "cocktails" and Hp-Tau probably because this damage is irreversible (Figure 5). However, the continuous provision of leptin by a cerebrally implanted leptin gene did prevent further damage in AD-model transgenic mice [98]. In addition, it probably did so by blocking the productions of $A \beta_{1-42}$, the source of the self-inducing toxic A $\mathrm{BOs}$ and Hp-Taues (Figure 5). Thus, leptin's anti-amyloidogenic activity is the basis of Neurotez's patent [7] for treating AD with leptin and its derivatives.

Finally, if leptin really can target $\mathrm{A} \beta \mathrm{O}$ s accumulation in humans as well as rodents, providing a steady supply of leptin may at least slow the progression of AD pathology in early-stage patients. Perhaps its effectiveness could also be increased with agents such as the CaSR $\left(\mathrm{Ca}^{2+}\right.$-sensing receptor)-antagonizing calcilytic drug NPS 2143 or a similarly acting one that stops the oversecretion of endogenous $A \beta s$ from both astrocytes and neurones of the human cerebral cortex $[84,106]$ and the $\sim 5-\mathrm{kDa}$ ABP (Amyloid- $\beta$ peptide) that selectively binds A $\beta$ Os [107].

\section{Author Contributions}

J.F.W. contributed to the development of the concept and wrote the article; B.C. carried out the experiments and contributed to concept development; and U.A, A.C. and I.D.P. provided intellectual input and key information, and helped in the preparation of the Manuscript.

\section{Conflicts of Interest}

The authors declare no conflict of interest. 


\section{References}

1. Duvernoy, H.; Cattin, F.; Risold, P.Y. The Human Hippocampus, 4th ed.; Springer: Heidelberg, Germany; New York, NY, USA; Dordrecht, The Netherlands; London, UK, 2013.

2. $\quad$ Ladyman, S.R.; Grattan, D.R. JAK-STAT and feeding. JAKSTAT 2013, 2, e23675.

3. Levin, B.E.; Magnan, C.; Dunn-Meynell, A.; Le Foll, C. Metabolic sensing in the brain: Who, what, where and how? Endocrinology 2011, 152, 2552-2557.

4. Li, M.-D. Leptin and beyond: An odyssey to the central control of body weight. Yale J. Biol. Med. 2011, 84, 1-7.

5. Tezapsidis, N.; Johnston, J.M.; Smith, M.A.; Ashford, J.W.; Casadesus, G.; Robakis, N.K.; Wo-lozin, B.; Perry, G.; Zhu, X.; Greco, S.J.; et al. Leptin: A novel therapeutic strategy for Alz-heimer's disease. J. Alzheimers Dis. 2009, 16, 731-740.

6. Irving, A.J.; Harvey, J. Leptin regulation of hippocampal synaptic function in health and disease. Philos. Trans. R. Soc. Lond. B Biol. Sci. 2013, 369, 20130155.

7. Tezapsidis, N. Leptin as an anti-amyloidogenic biologic and methods for delaying the onset and reducing Alzheimer's disease-like pathology. US Patent 8227408 B2, 24 July 2012.

8. Dehaene, S. Consciousness and the Brain: Deciphering How the Brain Decodes Our Thoughts; The Viking Press: New York, NY, USA, 2014.

9. Aimone, J.B.; Li, Y.; Lee, S.W.; Clemenson, G.D.; Deng, W.; Gage, F.H. Regulation and function of adult neurogenesis: From genes to cognition. Physiol. Rev. 2014, 94, 991-1026.

10. Cameron, H.A.; Glover, L.R. Adult neurogenesis: Beyond learning and memory. Annu. Rev. Psychol. 2015, 66, 53-81.

11. Drew, L.J.; Fusi, S.; Hen, R. Adult neurogenesis in the mammalian hippocampus: Why the dentate gyrus? Learn. Mem. 2013, 20, 710-729.

12. Hunsaker, M.R.; Kesner, R.P. The operation of pattern separation and pattern completion processes associated with attributes or domains of memory. Neurosci. Behav. Rev. 2013, 37, 36-58.

13. Seib, D.R.H.; Martin-Villalba, A. Neurogenesis in the normal ageing hippocampus: A mini review. Gerontology 2014, doi:10.1159/000368575.

14. Witter, M.P. Intrinsic and extrinsic wiring of CA3: Indications for connectional heterogeneity. Learn. Mem. 2007, 14, 705-713.

15. Yu, D.X.; Marchetto, M.C.; Gage, F.H. How to make a hippocampal dentate gyrus granule neuron. Development 2014, 141, 2366-2375.

16. Benarroch, E.E. Adult neurogenesis in the dentate gyrus. Neurology 2013, 8, 1443-1452.

17. Moscovitch, M.; Rosenbaum, R.S.; Gilboa, A.; Addis, D.R.; Westmacott, R.; Grady, C.; McAndrews, M.P.; Levine, B.; Black, S.M.; Winocur, G.; et al. Functional neuroanatomy of remote episodic, semantic and spatial memory: A unified account. J. Anat. 2005, 207, 35-66.

18. Rugg, M.D.; Johnson, J.D.; Park, H.; Uncapher, M.R. Encoding-retrieval overlap in human episodic memory: A functional neuroimaging perspective. Prog. Brain Res. 2008, 169, 339-352.

19. Kempermann, G. Adult Neurogenesis 2; Oxford University Press: Oxford, UK; New York, NY, USA, 2011.

20. Treves, A.; Tashiro, A.; Witter, M.E.; Moser, E.I. What is the dentate gyrus good for? Neuroscience 2008, 154, 1155-1172. 
21. Nikashiba, T.; Cushman, J.D.; Pelkey, K.A.; Renauddineau, S.; Buhl, D.L.; McHugh, T.J.; Barrera, V.; Chittajallu, R.; Iwamoto, K.S.; McBain, C.J.; et al. Young dentate granule cells mediate pattern separation, whereas old granule cells facilitate pattern completion. Cell $\mathbf{2 0 1 2}$, 149, 188-201.

22. Mongiat, L.A.; Schinder, A.F. Neuroscience: A price to pay for adult neurogenesis. Science 2014, 344, 594-595.

23. Basak, O.; Taylor, V. Stem cells of the adult mammalian brain and their niche. Cell Mol. Life Sci. 2009, 66, 1057-1072.

24. Goldman, S.A.; Chen, Z. Perivascular instruction of cell genesis and fate in the adult brain. Nat. Neurosci. 2011, 14, 1382-1389.

25. Morrens, J.; van den Broeck, W.; Kempermann, G. Glial cells in adult neurogenesis. Glia 2012, 60, 159-174.

26. Suh, H.; Deng, W.; Gage, F.H. Signaling in adult neurogenesis. Annu. Rev. Cell Dev. Biol. 2009, $25,253-275$.

27. Gould, E.; Cameron, H.A. Regulation of neuronal birth, migration, and death in the rat dentate gyrus. Dev. Neurosci. 1996, 18, 22-35.

28. Nacher, J.; Rosell, D.R.; Alonso-Liosa, G.; McEwen, B.S. NMDA receptor antagonist treatment induces a long-lasting increase in the number of proliferating cells, PSA-NCAM-immunoreactive granule neurons and radial glia in the adult rat dentate gyrus. Eur. J. Neurosci. 2001, 13, 512-520.

29. Antequara, D.; Portero, A.; Bolos, M.; Orive, G.; Hernández, R.M.; Pedraz, J.L.K.; Carro, E. Encapsulated VEGF-secreting cells enhance proliferation of neuronal progenitors in the hippocampus of A $\beta$ PP/Ps1 mice. J. Alzheimers Dis. 2012, 29, 187-200.

30. Attardo, A.; Fabel, K.; Krebs, J.; Haubensak, W.; Huttner, W.B.; Kempermann, G. Tis21 expression marks not only populations of neurogenic precursor cells but also new post-mitotic neurons in adult hippocampal neurogenesis. Cereb. Cortex 2010, 20, 301-314.

31. Mejia-Gervacio, S.; Murray, K.; Lledoi, P.-M. NKCCl controls GABAergic signaling and neuroblast migration in the postnatal forebrain. Neural Dev. 2011, doi:10.1186/1749-8104-6-4.

32. Bruel-Jungerman, E.; Lucassen, P.L.; Francis, F. Cholinergic influences on cortical development and adult neurogenesis. Behav. Brain Res. 2011, 221, 379-388.

33. Van der Borght, K.; Mulder, J.; Keijser, J.; Eggen, B.J.; Luiten, P.G.; van der Zee, E.A. Input from the medial septum regulates adult hippocampal neurogenesis. Brain Res. Bull. 2005, $67,117-125$.

34. Krzisch, M.; Temprana, S.G.; Mongiat, L.A.; Armida, J.; Schmutz, V.; Virtanen, M.A.; Kocher-Braissant, J.; Kraftsik, R.; Vutskits, L.; Conzelmann, K.K.; et al. Pre-existing astrocytes form functional processes on neurons generated in the adult hippocampus. Brain Struct. Funct. 2014, doi:10.1007/s00429-014-0768-y.

35. Dahl, H.A. Fine structure of cilia in the rat cerebral cortex. Z. Zellforsch. Mikrosk. Anat. 1963, 60, 369-386.

36. Berbari, N.F.; Malarkey, E.B.; Zaki, S.M.; Yazdi, S.M.; McNair, A.D.; Kippe, J.M.; Croyle, M.J.; Kraft, T.W.; Yoder, B.K. Hippocampal and cortical primary cilia are required for aversive memory in mice. PLOS ONE 2014, 9, e106576. 
37. Chakravarthy, B.; Gaudet, C.; Ménard, M.; Brown, L.; Atkinson, T.; Laferla, F.M.; Ito, S.; Armato, U.; dal Prà, I.; Whitfield, J. Reduction of the immunostainable length of the hppocampal dentate granule cells' primary cilia in 3 x AD-transgenic mice producing human $A \beta(1-42)$ and tau. Biochem. Biophys. Res. Commun. 2012, 427, 218-222.

38. Chakravarthy, B.; Gaudet, C.; Ménard, M.; Atkinson, T.; Chiarini, A.; dal Prà, I.; Whit-Field, J. The p75 neurotrophin receptor is localized to primary cilia in adult mouse hippocampal dentate gyrus granule cells. Biochem. Biophys. Res. Commun. 2010, 401, 458-462.

39. Händel, M.; Schultz, S.; Stenarius, A.; Schreff, M.; Erdtmann-Vouriliotis, M.; Schmidt, H.; Wolf, G.; Höllt, V. Selective targeting of somatostatin receptor 3 to neuronal cilia. Neuroscience 1999, 89, 909-926.

40. Stanić, D.; Malmgren, H.; He, H.; Scott, L.; Aperia, A.; Hökfelt, T. Developmental changes in frequency of the somatostatin receptor 3 protein. Brain Res. 2009, 1249, 101-112.

41. Kumamoto, N.; Gu, Y.; Wang, J.; Jamoschka, S.; Takemaru, K.-L.; Levine, J.; Ge, S. A role for primary cilia in glutamatergic synaptic integration of adult-born neurons. Nat. Neurosci. 2012, 15, 399-405.

42. Amador-Arjona, A.; Eelliott, J.; Miller, A.; Ginbey, A.; Pazour, G.J.; Enikolopov, G.; Roberts, A.J.; Terskikh, A.V. Primary cilia regulate proliferation of amplifying progenitors in adult hippocampus: Implications for learning and memory. J. Neurosci. 2011, 31, 9933-9944.

43. Malicki, J.; Avidor-Reiss, T. From cytoplasm into the cilium: Bon voyage. Organogenesis 2014, 10, 138-157.

44. Corbit, K.C.; Aanstad, P.; Singla, V.; Norman, A.R.; Stainier, D.Y.; Reiter, J.F. Verteb-rate smoothened functions at the primary cilium. Nature 2005, 437, 1018-1031.

45. Han, Y.G.; Spassky, N.; Romaguera-Ros, M.; Garcia-Verdugo, J.M.; Aguilar, A.; Schneider-Maunoury, S.; Alvarez-Buylla, A. Hedgehog signaling and primary cilia are required for formation of adult neural stem cells. Nat. Neurosci. 2008, 11, 277-284.

46. Goetz, S.C.; Ocbina, P.J.R.; Anderson, K.V. The primary cilium as a hedgehog signal transduction machine. Methods Cell Biol. 2009, 94, 199-222.

47. Breunig, J.J.; Sarkisian, M.R.; Arellano, J.I.; Morozov, Y.M.; Ayoub, A.E.; So-jitra, S.; Wang, B.; Flavell, R.A.; Rakic, P.; Town, T. Primary cilia regulate hippo-campal neurogenesis by mediating sonic hedgehog signaling. Proc. Natl. Acad. Sci. USA 2008, 105, 13127-13132.

48. Chiarini, A.; dal Prà, I.; Whitfield, J.F.; Armato, U. The killing of neurons by beta-amyloid peptides, prions, and proinflammatory cytokines. Ital. J. Anat. Embryol. 2006, 111, 221-246.

49. Sotthibundhu, A.; Li, Q.X.; Thangnipon, W.; Coulson, E.J. Abeta(1-42) stimulates adult SVZ neurogenesis through the p75 neurotrophin receptor. Neurobiol. Aging 2009, 30, 1975-1985.

50. Makuch, R.; Baratta, J.; Karaelias, L.D.; Lauterborn, J.C.; Gall, C.M.; Yu, J.; Robertson, R.T. Arrival of afferents and the differentiation of target neurons: Studies of developing cholinergic projections to the dentate gyrus. Neuroscience 2001, 104, 81-91.

51. Chakravarthy, B.; Ménard, M.; Ito, S.; Gaudet, C.; dal Prà I.; Armato, U.; Whit-Field, J.F. Hippocampal membrane-associated $\mathrm{p} 75^{\mathrm{NTR}}$ levels are increased in Alzheimer's disease. J. Alzheimers Dis. 2012, 29, 1-10.

52. Bernabeu, R.O.; Longo, F.M. The p75 neurotrophin receptor is expressed by adult mouse dentate progenitor cells and regulates neuronal and non-neuronal cell genesis. BMC Neurosci. 2010, 11, 136. 
53. Catts, V.S.; Al-Menhali, N.; Burne, T.H.; Colditz, M.J.; Coulson, E.J. The p75 neuro-trophin receptor regulates hippocampal neurogenesis and related behaviours. Eur. J. Neurosci. 2010, 28, 883-892.

54. Colditz, M.J.; Catts, V.S.; Al-Menhali, N.; Osborne, G.W.; Bartlett, P.F.; Coulson, E.J. p75 neurotrophin receptor regulates basal and fluoxetine-stimulated hippocampal neurogenesis. Exp. Brain Res. 2010, 200, 161-167.

55. Hartmann, M.; Brigadski, T.; Erdmann, K.S.; Holtmann, B.; Sendtner, M.; Narz, F.; Lessmann, V. Truncated TrkB receptor-induced outgrowth of dendritic filopodia involves the p 75 neurotrophin receptor. J. Cell Sci. 2004, 117, 5803-5814.

56. Klein, R.; Conway, D.; Parada, L.F.; Barbacid, M. The trkB tyrosine protein kinase gene codes for a second neurogenic receptor that lacks the catalytic kinase domain. Cell 1990, 61, 647-656.

57. Yacoubian, T.A.; Lo, D.C. Truncated and full-length trkB receptors regulate distinct modes of dendritic growth. Nat. Neurosci. 2000, 3, 342-349.

58. He, Q.; Wang, G.; Wakade, S.; Dasgupta, S.; Dinkins, M.; Kong, J.N.; Spassieva, S.D.; Bieberich, E. Primary cilia in stem cells and neural progenitors are regulated by neutral sphingomyelinase 2 and ceramide. Mol. Biol. Cell 2014, 25, 1715-1729.

59. Wang, G.; Krishnamurthy, K.; Bieberich, E. Regulation of primary cilia formation by ceramide. J. Lipid Res. 2009, 50, 2103-2110.

60. Brann, A.B.; Scott, R.; Neuberger, Y.; Abulafia, D.; Boldin, S.; Fainzilber, M.; Futerman, A.H. Ceramide signaling downstream of the p75 neurotrophin receptor mediates the effects of nerve growth factor on outgrowth of cultured hippocampal neurons. J. Neurosci. 1999, 19, 8199-8206.

61. Schwarz, A.; Futerman, A.H. Inhibition of sphingolipid synthesis, but not degradation, alters the rate of dendritic growth in cultured hippocampal neurons. Brain Res. Dev. Brain Res. 1998, 108, $125-130$.

62. Dobrowski, R.T.; Carter, B.D. Coupling of the p75 neurotrophin receptor to sphingo-lipid signaling. Ann. N. Y. Acad. Sci. 1998, 845, 32-45.

63. Berbari, N.F.; Johnson, A.D.; Lewis, J.S.; Askwith, C.C.; Mykytyn, K. Identification ciliary localization sequences within the third intracellular loop of $\mathrm{G}$ protein-coupled receptors. Mol. Biol. Cell 2008, 19, 1540-1547.

64. Einstein, E.B.; Patterson, C.A.; Hon, B.J.; Regan, K.A.; Reddi, J.; Melnikoff, D.E.; Mateer, M.J.; Schultz, S.; Johnson, B.N.; Tallent, M.K. Somatostatin signaling in neuronal cilia is critical for object recognition memory. J. Neurosci. 2010, 30, 4306-4314.

65. Green, J.A.; Gu, C.; Mykytyn, K. Heteromerization of ciliary G protein-coupled receptors in the mouse brain. PLOS ONE 2012, 7, e46304.

66. Khan, U.A.; Liu, L.; Provenzano, F.A.; Berman, D.E.; Profaci, C.P.; Sloan, R.; Mayeux, R.; Duff, K.E.; Small, S.A. Molecular drivers and cortical spread of lateral entorhinal cortex dysfunction in preclinical Alzheimer's disease. Nat. Neurosci. 2014, 17, 304-311.

67. Penzes, P.; Vanleeuwen, J.E. Impaired regulation of synaptic actin cytoskeleton in Alzheimer's disease. Brain Res. 2011, 67, 184-192.

68. Hubin, E.; van Nuland, N.A.; Broersen, K.; Pauwels, K. Transient dynamics of A $\beta$ contribute to toxicity in Alzheimer's disease. Cell. Mol. Life Sci. 2014, 71, 3507-3521. 
69. Klein, W.L. Synaptotoxic amyloid- $\beta$ oligomers: A molecular basis for the cause, diag-nosis and treatment of Alzheimer's disease? J. Alzheimers Dis. 2013, 33 (Suppl. S1), S49-S63.

70. Selkoe, D.J.; Mandelkow, E.; Holtzman, D.M. (Eds.) The Biology of Alzheimer Disease; Cold Spring Harbor Laboratory Press: Cold Spring Harbor, NY, USA, 2012.

71. Cheng, X.; Wu, J.; Geng, M.; Xiong, J. The role of synaptic activity in the regulation of amyloid beta levels in Alzheimer's disease. Neurobiol. Aging 2014, 35, 1217-1232.

72. Choy, R.W.; Cheng, Z.; Schekman, R. Amyloid precursor protein (APP) traffic from the cell surface via endosomes for amyloid $\beta$ production in the trans-Golgi network. Proc. Natl. Acad. Sci. USA 2012, 109, E2077-E2082.

73. Zlokovic, B.V. Neurovascular pathways to neurodegeneration in Alzheimer's disease and other disorders. Nat. Rev. Neurosci. 2011, 12, 722-738.

74. Jawhar, S.; Wirths, O.; Bayer, T.A. Pyroglutamate amyloid- $\beta$ (A $\beta)$ : A hatchet man in Alzheimer disease. J. Biol. Chem. 2011, 286, 38825-38832.

75. Burgos-Ramos, E.; Hervás-Aguilar, A.; Aguado-Liera, D.; Puebla-Jiménez, L.; Hernández-Pinto, A.M.; Barrios, V.; Arilla-Ferreiro, E. Somatostatin and Alzheimer's disease. Mol. Cell. Endocrinol. 2008, 286, 104-111.

76. Ramos, B.; Baglietto-Vargas, D.; del Rio, J.C.; Moreno-Gonzalez, I.; Santa-Maria, C.; Jimenez, S.; Caballero, C.; Lopez-Tellez, J.F.; Khan, Z.U.; Ruano, D.; et al. Early neuropathology of somatostatin/NPY GABAergic cells in the hippocampus of a PSI $\times$ APP transgenic model of Alzheimer's disease. Neurobiol. Aging 2006, 27, 1658-1672.

77. Ito, S.; Ménard, M.; Atkinson, T.; Gaudet, C.; Brown, L.; Whitfield, J.; Chakravarthy, B. Involvement of insulin-like growth factor 1 receptor signaling in the amyloid-beta peptide oligomers-induced p75 neurotrophin receptor protein expression in mouse hippocampus. J. Alzheimers Dis. 2012, 31, 493-506.

78. Bruno, A.M.; Leon, W.; Fragosos, G.; Mushynski, W.; Almazan, G.; Cuello, A.C. Amyloid beta-induced nerve growth factor dysmetabolism in Alzheimer's disease. J. Neuropathol. Exp. Neurol. 2009, 68, 857-869.

79. Shruster, A.; Melamed, E.; Offen, D. Neurogenesis in the aged and neurodegenerative brain. Apoptosis 2010, 15, 1415-1421.

80. Waldau, R.; Shetty, A.K. Behavior of neural stem cells in the Alzheimer brain. Cell. Mol. Life Sci. 2008, 65, 2372-2384.

81. Yu, Y.; He, J.; Zhang, Y.; Luo, H.; Zhu, S.; Yang, Y.; Zhao, T.; Wu, J.; Huang, Y.; Kong, J.; et al. Increased hippocampal neurogenesis in the progressive stage of Alzheimer's disease phenotype in an APP/PS1 double transgenic mouse model. Hippocampus 2009, 19, 1247-1253.

82. Barucker, C.; Harmeier, A.; Weiske, J.; Fauler, B.; Albring, K.F.; Prokop, S.; Hildebrand, P.; Lurz, R.; Heppner, F.L.; Huber, O.; et al. Nuclear trans-location uncovers the amyloid peptide $\mathrm{A} \beta 42$ as a regulator of gene transcription. J. Biol. Chem. 2014, 289, 20182-20191.

83. Maloney, B.; Lahiri, D.K. The Alzheimer's amyloid $\beta$-peptide $(\mathrm{A} \beta)$ binds a specific DNA A $\beta$-interacting domain (A $\beta$ ID) in the APP, BACE1, and APOE promoters in a sequence-specific manner: Characterizing a new regulatory motif. Gene 2011, 488, 1-12. 
84. Dal Prà, I.; Chiarini, A.; Gui, L.; Chakravarthy, B.; Pacchiana, R.; Gardenal, E.; Whitfield, J.F.; Armato, U. Do astrocytes collaborate with neurons in spreading the "infectious" A $\beta$ and Tau drivers of Alzheimer's disease? Neuroscientist 2015, 21, 9-29.

85. Ittner, L.M.; Götz, J. Amyloid- $\beta$ and tau-A toxic pas de deux in Alzheimer's disease. Nat. Rev. Neurosci. 2011, 12, 67-72.

86. Bloom, G.S. Amyloid- $\beta$ and tau: The trigger and bullet in Alzheimer disease patho-genesis. JAMA Neurol. 2014, 71, 505-508.

87. Ding, H.; Dolan, P.J.; Johnson, G.V.W. Histone deacetylase 6 interacts with the micro-tubuleassociated protein tau. J. Neurochem. 2008. 106, 2119-2130.

88. Xiong, Y.; Zhao, K.; Wu, J.; Xu, Z.; Jin, S.; Zhang, Y.Q. HDAC6 mutations rescue human tauinduced induced microtubule defects in Drosophila. Proc. Natl. Acad. Sci. USA 110, 46044609.

89. Seward, M.E.; Swanson, E.; Norambuena, A.; Reimann, A.; Cochran, J.N.; Li, R.; Robertson, E.D.; Bloom, G.S. Amyloid- $\beta$ signals through tau to drive ectopic neuronal cell cycle reentry in Alzheimer's disease. J. Cell Sci. 2013, 126, 1278-1286.

90. Larson, M.; Sherman, M.A.; Amar, F.; Nuvolone, M.; Schneider, J.A.; Bennett, D.A.; Aguzzi, A.; Lesnć, S.E. The complex PrP(c) Fyn couples human oligomeric A $\beta$ with pathological tau changes in Alzheimer's disease. J. Neurosci. 2012, 32, 16857-16871.

91. Ward, S.M.; Himmelstein, D.S.; Lancia, J.K.; Binder, L.I. Tau oligomers and tau toxicity in neurodegenerative disease. Biochem. Soc. Trans. 2012, 40, 667-671.

92. Nisbet, R.M.; Polanco, J.-C.; Ittner, L.M.; Götz, J. Tau aggregation and its interplay amyloid- $\beta$. Acta Neuropathol. 2015, 129, 207-220.

93. Spires-Jones, T.L.; Hyman, B.T. The intersection of amyloid beta and tau at synapses in Alzheimer's disease. Neuron 2014, 82, 756-771.

94. Absalon, S.; Kochanek, D.M.; Raghavan, V.; Krichevsky, A.M. MiR-26b, upregulated in Alzheimer's disease, activates cell cycle entry tau phosphorylation, and apoptosis in postmitotic neurons. J. Neurosci. 2013, 33, 14645-14659.

95. Hussman, J.W.; Nochlin. D.; Vincent, J. Mitotic activation: A convergent mechanism for a cohort of neurodegenerative diseases. Neurobiol. Aging 2000, 21, 815-828.

96. Greco, S.J.; Sarkar, S.; Casadesus, G.; Zhu, X.; Smith, M.A.; Ashford, J.W.; Johston, J.M.; Tezapsidis, N. Leptin inhibits glycogen synthase kinase-3 $\beta$ to prevent tau phosphorylation in neuronal cells. Neurosci. Lett. 2009, 455, 191-194.

97. Marwarha, G.; Ghribi, O. Leptin signaling and Alzheimer's disease. Am. J. Neurodegener. Dis. 2012, 1, 245-265.

98. McGregor G.; Malekizadeh, Y.; Harvey, J. Minireview: Food for thought: Regulation of synaptic function by metabolic hormones. Mol. Endocrinol. 2015, 29, 3-13.

99. Marwarha, G.; Raza, S.; Meiers, C.; Ghribi, O. Leptin attenuates BACE1 expression and amyloid- $\beta$ genesis via the activation of SIRT1 signaling pathway. Biochim. Biophys Acta 2014, 1842, 1587-1595.

100. Pérez-González, R.; Alvira-Botero, M.X.; Robayo, O.; Antequera, D.; Garzón, M.; Martin-Moreno, A.M.; Brera, B.; de Ceballos, M.I.; Carro, E. Leptin gene therapy attenuates 
neural damages evoked by amyloid- $\beta$ and reduces memory deficits in APP/PS1 mice. Gene Ther. 2014, 21, 298-308.

101. Garza, J.C.; Guo, M.; Zhang, W.; Lu, X.-Y. Leptin increases adult hippocampal neurogenesis in vivo and in vitro. J. Biol. Chem. 2008, 283, 18238-18247.

102. Garza, J.C.; Guo, M.; Zhang, W.; Lu, X.-Y. Leptin restores adult hippo-campal neurogenesis suppressed by chronic unpredictable stress and reverses glucocorticoid-induced inhibition of GSK3 $\beta / \beta$-catenin signaling. Mol. Psychiatry 2012, 17, 790-808.

103. Pérez-González, R.; Antequera, D.; Vargas, T.; Spuch, C.; Bolós, M.; Carro, E. Leptin induces proliferation of neuronal progenitors and neuroprotection in a mouse model of Alzheimer's disease. J. Alzheimers Dis. 2011, 24, 17-25.

104. Kenney, A.M.; Rowitch, D.H. Sonic hedgehog promotes $\mathrm{G}_{1}$ cyclin expression expression and sustained cell cycle progression in mammalian neuronal precursors. Mol. Cell. Biol. 2000, 20, 9055-9067.

105. Shanley, L.J.; O’Malley, D.; Irving, A.J.; Ashford, M.L.; Harvey, J. Leptin inhibits epileptiform-like activity in rat hippocampal neurones via PI3-kinase-driven activation of BK channels. J. Physiol. 2002, 545, 933-944.

106. Armato, U.; Chiarini, A.; Chakravarthy, B.; Chioffi, F.; Pacchiana, R.; Colarusso, E.; Whitfield. J.F.; dal Prà, I. Calcium-sensing receptor antagonist (calcilytic) (NPS2143 specifically blocks the the increased secretion of endogenous fibrillary or soluble $A \beta_{25-35}$ in human cortical astrocytes and neurons-Therapeutic relevance to Alzheimer's disease. Biochim. Biophys. Acta 2013, 1832, 1634-1652.

107. Chakravarthy, B.; Ménard, M.; Brown, L.; Hewitt, M.; Atkinson, T.; Whitfield, J.F. A synthetic peptide corresponding to a region of the pericentriolar material 1 (PCM-1) protein binds $\beta$ amyloid (A $\left.\beta_{1-42}\right)$ oligomers. J. Neurochem. 2013, 126, 415-424.

108. Greco, S.J.; Sarkar, S.; Johnston, J.M.; Zhu, X.; Su, B.; Casadesus, G.; Ashford, J.W.; Smith, M.A.; Tezapsidis, N. Leptin reduces Alzheimer's disease-related tau phosphorylation in neuronal cells. Biochem. Biophys. Res. Commun. 2008, 376, 536-541.

109. Chakravarthy, B.; Gaudet, C.; Ménard, M.; Atkinson, T.; Brown, L.; Laferla, F.M.; Armato, U.; Whitfield, J.F. Amyloid-beta peptides stuimulate the expression of the p75(NTR) neurotrophin receptor in SHSY5Y human neuroblastoma cells and AD transgenic mice. J. Alzheimers Dis. 2010, 19, 915-925.

110. Whitfield, J.F.; Chakravarthy, B.; Chiarini, A.; Dal Prá, I.; Armato, U. The leptin receptor, a driver of adult neurogenesis that may treat Alzheimer's disease, has been found in murine dentate gran-ule cells' ciliary toolbox. In Horizons in Neuroscience Research; Costa, A., Villalba, E., Eds.; Nova Science Publishers: Hauppauge, NY, USA, 2015; Volume 21.

(C) 2015 by the authors; licensee MDPI, Basel, Switzerland. This article is an open access article distributed under the terms and conditions of the Creative Commons Attribution license (http://creativecommons.org/licenses/by/4.0/). 